\title{
Anti-Mayaro virus activity of Cassia australis extracts (Fabaceae, Leguminosae)
}

\author{
Kassia C W Spindola ${ }^{1 *}$, Naomi K Simas ${ }^{2}$, Tiago S Salles ${ }^{4}$, Marcelo D F de Meneses ${ }^{3}$, Alice Sato ${ }^{5}$, Davis Ferreira ${ }^{3}$, \\ Wanderson Romão ${ }^{6}$ and Ricardo M Kuster ${ }^{1}$
}

\begin{abstract}
Background: The arthropod-borne Mayaro virus (MAYV) causes 'Mayaro fever', a disease of medical significance, primarily affecting individuals in permanent contact with forested areas in tropical South America. Studies showed that the virus could also be transmitted by the mosquito Aedes aegypti. Recently, MAYV has attracted attention due to its likely urbanization. To date, there are no drugs that can treat this illness.

Methods: Fractions and compounds were obtained by chromatography from leaf extracts of $C$. australis and chemically identified as flavonoids and condensed tannins using spectroscopic and spectrometric techniques (UV, NMR, and ESI-FT-ICR MS). Cytotoxicity of EtOAc, $n-\mathrm{BuOH}$ and EtOAc-Pp fractions were measured by the dye-uptake assay while their antiviral activity was evaluated by a virus yield inhibition assay. Larvicidal activity was measured by the procedures recommended by the WHO expert committee for determining acute toxicity.

Results: The following group of substances was identified from EtOAc, $n-\mathrm{BuOH}$ and EtOAc-Pp fractions: flavones, flavonols, and their glycosides and condensed tannins. EtOAc and n-BuOH fractions inhibited MAYV production, respectively, by more than $70 \%$ and $85 \%$ at $25 \mu \mathrm{g} / \mathrm{mL}$. EtOAc-Pp fraction inhibited MAYV production by more than $90 \%$ at $10 \mu \mathrm{g} / \mathrm{mL}$, displaying a stronger antiviral effect than the licensed antiviral ribavirin. This fraction had an excellent antiviral effect $\left(I C_{90}=4.7 \pm 0.3 \mu \mathrm{g} / \mathrm{mL}\right)$, while EtOAc and $n$-BuOH fractions were less active $\left(I C_{90}=89.1 \pm 4.4 \mu \mathrm{g} / \mathrm{mL}\right.$ and $I_{90}=40.9 \pm 5.7 \mu \mathrm{g} / \mathrm{mL}$, respectively).
\end{abstract}

Conclusions: $C$. australis can be used as a source of compounds with anti-Mayaro virus activity. This is the first report on the biological activity of $C$. australis.

Keywords: Cassia australis, Flavonoids, Tannins, Antiviral, MAYV, Larvicidal activity, Aedes aegypti

\section{Background}

In Brazil, MAYV is endemic in the Amazon region, but Mayaro fever outbreaks have occurred in other regions in Brazil [1,2]. Most arboviruses isolated in the Amazon region are maintained in nature by different life cycles, involving different vectors and vertebrate hosts. Oropouche virus, for example, is transmitted to humans in urban areas by the midges Culicoides paraensis, and vertebrates such as sloths, monkeys and birds play a role in the maintenance of the virus cycle [3]. Likewise, Mayaro and yellow fever viruses are transmitted by the mosquito Haemagogus janthinomys in the jungle, and monkeys are

\footnotetext{
* Correspondence: kawaldhelm@gmail.com

'Natural Product Research Institute, Center of Health Sciences, Federal University of Rio de Janeiro, Rio de Janeiro, Brazil

Full list of author information is available at the end of the article
}

the main hosts [4]. On the other hand, dengue virus has a simpler cycle whereby the serotypes are directly transmitted to humans by Aedes aegypti mosquito bites [5]. In addition, imported MAYV cases in other countries from tourists who visited the Amazon region have been described [6]. MAYV can also be transmitted by the vectors Aedes aegypti and A. albopictus, which raises the concern for urban areas. It is very important to point out that MAYV is closely related to the Chikungunya virus, also transmitted by the mosquitoes Aedes aegypti and A. albopictus, which has recently reached Europe and the Americas and is now counting nearly 800 of autochthones infections in Brazil since the first detected case in this country in August 2014 [7,8].

Natural products are becoming very attractive because of their low cytotoxicity, the rapid degradation in the 
environment, and because of the complexity of the chemistry in these products, that should limit resistance and increase the applicability of use, such as vector control studies [9].

The majority of the available antiviral drugs are concentrated in a small number of viruses, such as HIV, Herpes and Influenza [10]. Nevertheless, research efforts to explore the potential of natural products as sources of novel low toxicity and high selectivity antiviral substances have increased lately [11]. Because there are many approaches for the use of natural products, the modes of action or the active components they contain and the metabolic pathways they interact must be studied. This can be accomplished initially by in vitro studies such as the cell culture approach in this paper.

The genus Cassia (Fabaceae, Leguminosae) comprises more than 600 species including shrubs, trees and herbs, distributed in tropical and subtropical regions all over the world. The separation of the genus Senna from the genus Cassia has been, and still is, the subject of many discussions [12]. The species under study was originally classified as Cassia australis Vellozo and in 1982 by Irwin and Barneby it was transferred to Senna with the name: Senna australis (Vell.) H.S.Irwin \& Barneby. Afterwards, this species has been renamed Senna appendiculata (Vogel) [13].

In Brazilian ecosystems, particularly in the Atlantic forest, the genus Senna is widespread, with some species in the Southeast greatly appreciated for the beauty of its flowers, and therefore widely used as ornamental plants [14]. Due to the traditional use, several species, many already described in the literature, are medicinally used worldwide [15-20]. Cassia australis is a medium sized shrub and may reach up to 2.5 meters of diameter. It occurs at Brazilian coast sandbank, mainly in Rio de Janeiro, Espirito Santo, Bahia, Sergipe, Alagoas and Pernambuco states [21]. The genus Cassia is known for the presence of a variety of compounds. Anthraquinones are the main class of compounds isolated from it [17,22-25]. However, previous investigations led to the isolation of flavonoids [26-29], piperidine alkaloids [30], stilbenoids [30] and aliphatic esters [16]. So far, there is no paper about the phytochemistry and biological activity of Cassia australis.

For most mosquito-transmitted viruses, there are no licensed antiviral drugs or vaccines available. MAYV is an example of an arthropod-borne virus, mainly found in South America tropical areas, which affects primarily individuals in permanent contact with forested areas and causes the Mayaro fever. In this study, EtOAc, $n-\mathrm{BuOH}$ and EtOAc-Pp fractions containing flavonoids and other classes of phenolics compounds were obtained from the leaves of Cassia australis Vellozo and investigated for their in vitro antiviral activity against MAYV replication in Vero cells and larvicidal activity against Aedes aegypti larvae.

\section{Methods}

\section{Plants, cells and viruses}

Cassia australis leaves were collected in December 2008 in Rio de Janeiro State, and identified by Alice Sato. Voucher specimens (No. 652HUNI) are deposited in the herbarium of the University of Rio de Janeiro (UNIRIO), Brazil.

Vero cells (African green monkey kidney, ATCC CCL81) were maintained at $37^{\circ} \mathrm{C}, 5 \% \mathrm{CO}_{2}$, in Dulbecco's modified Eagle's medium (DMEM) (Life Technologies, USA) supplemented with $5 \%$ fetal bovine serum (Cultilab, BRA), $50 \mathrm{IU} / \mathrm{mL}$ of penicillin, and $50 \mu \mathrm{g} / \mathrm{mL}$ of streptomycin (Sigma-Aldrich, USA). Mayaro virus (ATCC VR-66, lineage TR 4675) was propagated in Vero cells and viral stocks kept at $-70^{\circ} \mathrm{C}$ until use.

Aedes aegypti eggs were obtained at the Brazilian Army Institute of Biology. They were kept in the tray containing tap water at optimal conditions $\left(28 \pm 1^{\circ} \mathrm{C}\right)$. After $48 \mathrm{hrs}$ of incubation, the eggs were used. The 4th instar larvae were used in the study.

\section{Extraction, fractionation, and purification for achievement of fractions and compounds}

Air-dried leaves $(850 \mathrm{~g})$ were extracted with $\mathrm{MeOH}: \mathrm{H}_{2} \mathrm{O}$ $(8: 2)$ at room temperature by static maceration over 10 days. After concentration under reduced pressure, the methanol extract $(25 \mathrm{~g})$ was suspended in $\mathrm{MeOH}: \mathrm{H}_{2} \mathrm{O}$ (9:1), and partitioned with hexane. After removal of the methanol from the defatted extract, the remaining aqueous solution was partitioned successively with $\mathrm{CH}_{2} \mathrm{Cl}_{2}$, EtOAc, and $n-\mathrm{BuOH}$. Two grams of the EtOAc extract, soluble in $\mathrm{H}_{2} \mathrm{O}: \mathrm{MeOH}$ (9:1), were applied to a XAD-2 column (procedure A), and chromatographed in a stepwise gradient with $\mathrm{H}_{2} \mathrm{O}: \mathrm{MeOH}$ (10:0/0:10). $150 \mathrm{ml}$ of each combination of solvents were eluted through the column and fractions of $150 \mathrm{ml}$ were collected. The fraction obtained with $100 \%$ of water was named EtOAc-Pp. From $\mathrm{H}_{2} \mathrm{O}: \mathrm{MeOH}$ (50:50) fraction, after chromatography on Sephadex LH-20 (MeOH: $\mathrm{H}_{2} \mathrm{O}-1: 1$, mobile phase) (procedure B), the flavone tricetin- $4{ }^{\prime}$-methoxy-3' $-\beta$-glucoside [31] was obtained. The same procedures $A$ and $B$ were applied to $n-\mathrm{BuOH}$ extract to obtain the flavone vicenin-2 [32].

\section{Reverse-phase HPLC-DAD-UV, TLC, NMR and ESI-(-)-FT- ICR MS analyses}

HPLC-DAD-UV (High Performance Liquid Chromatography with Diode Array Detector), TLC (Thin Layer Chromatography), NMR (Nuclear Magnetic Resonance) and ESI(-)-FT-ICR MS (Electrospray ionization with Fourier Transform Ion Cyclotron Resonance Mass Spectrometry) 
were used to analyze the chemical composition of EtOAc, $n-\mathrm{BuOH}, \mathrm{EtOAc-Pp}$ fractions and compounds isolated from them.

The mobile phase for HPLC-DAD analysis consisted of solvent (A) $1 \%$ phosphoric acid in water and solvent (B) $1 \%$ phosphoric acid in methanol and was used under the following gradient: $5 \%$ of B to $70 \%$ of B in A for $55 \mathrm{~min}$. The flow rate was $1 \mathrm{~mL} / \mathrm{min}$ and the injection volume $20 \mu \mathrm{L}$. The UV-vis spectra were recorded from 210 to $400 \mathrm{~nm}$ and the detector focused on 254 and $365 \mathrm{~nm}$. TLC was performed on silica gel plates $60 \mathrm{~F}_{254}$ (Merck, $20 \times 20 \mathrm{~cm}, 0.5 \mathrm{~mm}$ thickness), using $n$-butanol-wateracetic acid (4:5:1) and chloroform-methanol (9:1) as mobile phases. After elution, TLC plates were observed under $254 \mathrm{~nm}$ UV light and then sprayed successively with solutions of NP (2-aminoethyldiphenylborinate 1\% in methanol) and PEG-4000 (polyethylene glycol 5\% in ethanol) (both by Sigma-Aldrich, USA) before examination under $365 \mathrm{~nm}$ UV light. Cassia australis extracts and pure compounds were analyzed by an ultra-high resolution and accuracy mass spectrometer (model 9.4 T Solarix, Bruker Daltonics, Bremen, Germany). Briefly, the samples were dissolved in acetonitrile/ammonium hydroxide (99.9/0.1 v/v \%) mixture to a final concentration of $10 \mu \mathrm{g} \mathrm{mL} \mathrm{m}^{-1}$. The mass spectrometer was set to operate in negative ion mode, $\operatorname{ESI}(-)$, over a mass range of $\mathrm{m} / \mathrm{z}$ 200-2000. The parameters of the ESI(-) source were as follows: nebulizer gas pressure of 0.5-1.0 bar, capillary voltage of $3-3.5 \mathrm{kV}$, and transfer capillary temperature of $250^{\circ} \mathrm{C}$. The spectrum was processed using the Compass Data Analysis software package (Bruker Daltonics, Bremen, Germany). A resolving power, $\mathrm{m} / \Delta \mathrm{m}_{50 \%} \approx 500000$, in which $\Delta \mathrm{m}_{50 \%}$ is the full peak width at half-maximum peak height, of $\mathrm{m} / \mathrm{z} \approx 400$ and a mass accuracy of $<1 \mathrm{ppm}$ provided the unambiguous molecular formula assignments for singly charged molecular ions. Elemental compositions of the compounds were determined by measuring the $\mathrm{m} / \mathrm{z}$ values. NMR analysis $\left({ }^{1} \mathrm{H}-\mathrm{NMR}, \mathrm{COSY}, \mathrm{HSQC}\right.$ and HMBC) were recorded on Varian spectrometer MR-400 operating at $400 \mathrm{MHz}$. The samples were solubilized in DMSO- $\mathrm{d}_{6}$ and TMS was used as external standard.

Final compound analysis was performed by NMR (DMSO- $\mathrm{d}_{6}$ ), FT-ICR-ESI-MS, UV spectral analysis, and by comparison with literature values.

\section{Cytotoxicity assay}

Cytotoxicity analysis was performed using the dye-uptake method modified from Borenfreund and Puerner [33]. Vero cells grown in 96-well microplates were treated with culture media containing different concentrations of the substances. After 24 hours, the medium was replaced by a solution of $50 \mu \mathrm{g} / \mathrm{mL}$ neutral red, the cells were incubated for 3 hours at $37^{\circ} \mathrm{C}, 5 \% \mathrm{CO}_{2}$ and then fixed and extracted with $20 \%$ formaldehyde and $50 \%$ methanol, $1 \%$ acetic acid. Absorbance was read at $490 \mathrm{~nm}$, using a spectrophotometer, to detect neutral red incorporation by living cells. Absorbance results were used to calculate, by regression analysis, the concentrations of the tested substances capable of reducing cell viability by $50 \%$ and $90 \%$ relative to controls $\left(\mathrm{CC}_{50}\right.$ and $\mathrm{CC}_{90}$, respectively).

\section{Antiviral activity assay}

For the antiviral activity, confluent Vero cell monolayers grown in 24-well plates were infected with MAYV (multiplicity of infection $=0.1$ ) for 1 hour, then rinsed with PBS and treated for 24 hours (at $37^{\circ} \mathrm{C}$ and $5 \% \mathrm{CO}_{2}$ ) with different concentrations $(0-100 \mu \mathrm{g} / \mathrm{ml})$ of the substances diluted in culture medium. After treatment, culture supernatants were recovered and used for titration of extracellular infectious virus particles. Ribavirin (SigmaAldrich, USA) was used as positive control for MAYV replication inhibition. For each substance or extract, $\mathrm{IC}_{50}$ and $\mathrm{IC}_{90}$ values were calculated and used to obtain a selectivity index (SI), expressed as the ratio $\mathrm{CC}_{50} / \mathrm{IC}_{50}$, and to estimate relative potency (RP) as the ratio between ribavirin (reference substance) $\mathrm{IC}_{90}$ and the tested substance's $\mathrm{IC}_{90}$. Results were presented as mean inhibitory/cytotoxic concentration $\pm \mathrm{SD}$, and $t$-tests were used to evaluate the statistical significance of treatments relative to controls. Pvalues $<0.05$ were considered statistically significant.

\section{Virus yield assay}

For virus titration, confluent cell monolayers in 24-well plates were infected with serial dilutions of recovered supernatants from the assays for 1 hour at $37^{\circ} \mathrm{C}, 5 \% \mathrm{CO}_{2}$. After inoculum removal, cells were rinsed with PBS and the monolayer was incubated with fresh medium with 2\% carboxymethylcellulose (Sigma-Aldrich, USA) for 48 hours at $37^{\circ} \mathrm{C}, 5 \% \mathrm{CO}_{2}$. Finally, cells were fixed with $20 \%$ formaldehyde and stained with $0.5 \%$ crystal violet in $20 \%$ ethanol, and viral plaques were counted.

\section{Results}

\section{Flavonoid aglycones, flavonoid glycosides and tannins} were found in extracts of $C$. australis leaves

HPLC-DAD-UV analysis of EtOAc, $n$-BuOH and EtOAc$\mathrm{Pp}$ fractions indicated different flavonoid profiles. Flavonoid aglycones and flavonoid monoglycosides with retention time (RT) greater than $40 \mathrm{~min}$., predominated in EtOAc fraction (Figure 1A and B), while flavonoid diglycosides, more polar compounds (30 min. $<\mathrm{RT}<40 \mathrm{~min}$ ) (Figure $1 \mathrm{C}$ and $\mathrm{D}$ ), predominated in $n-\mathrm{BuOH}$ fraction. HPLC-DAD analysis of EtOAc-Pp showed more polar compounds (20 min $<\mathrm{RT}<50 \mathrm{~min}$ ), like tannins and flavonoid diglycosides (Figure $1 \mathrm{E}$ and $\mathrm{F}$ ).

All the ESI(-)FT-ICR MS analyses (Table 1) were made in negative ion mode. The structures were suggested based on their ultra-high resolution and accuracy mass. 


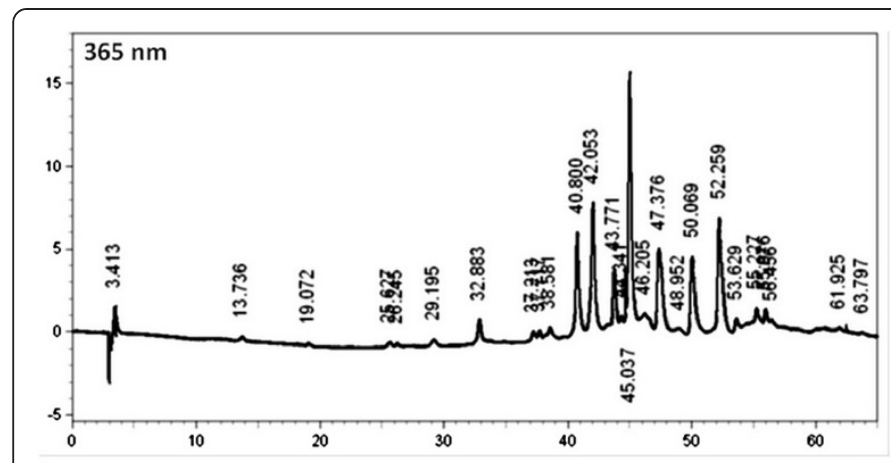

A
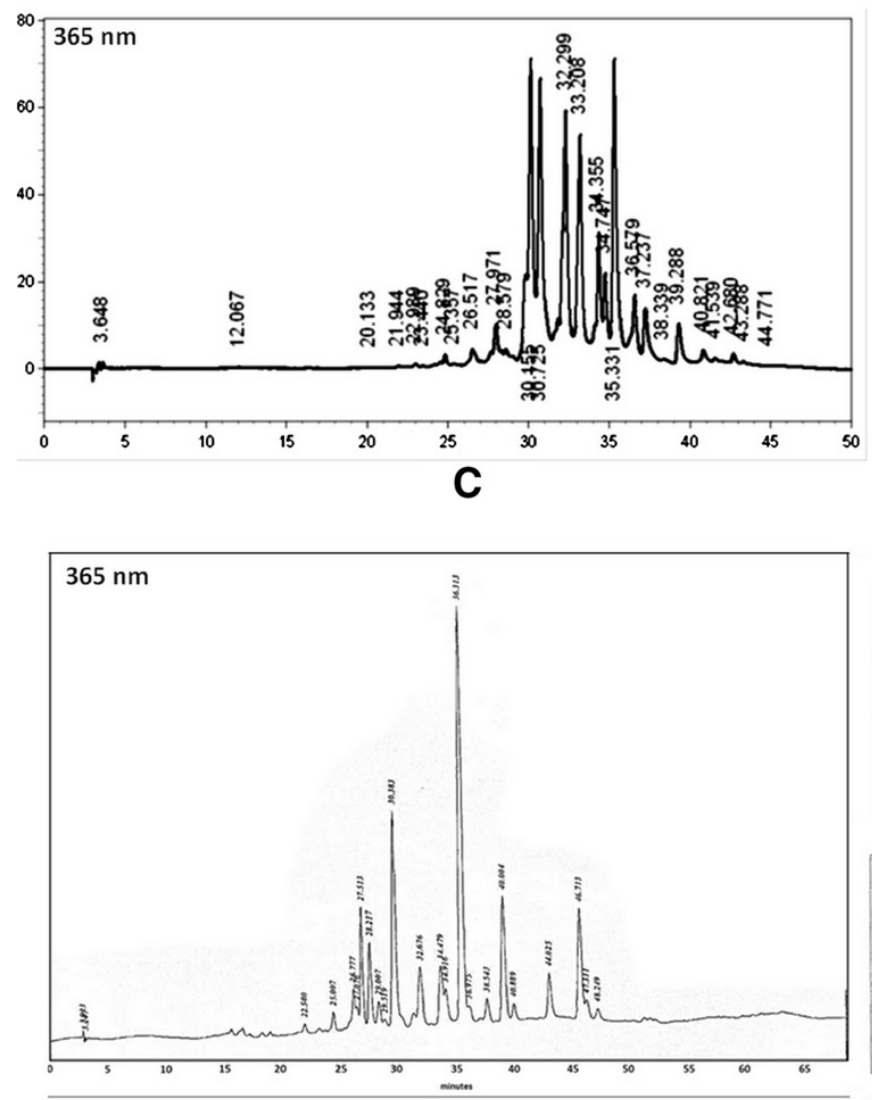

E
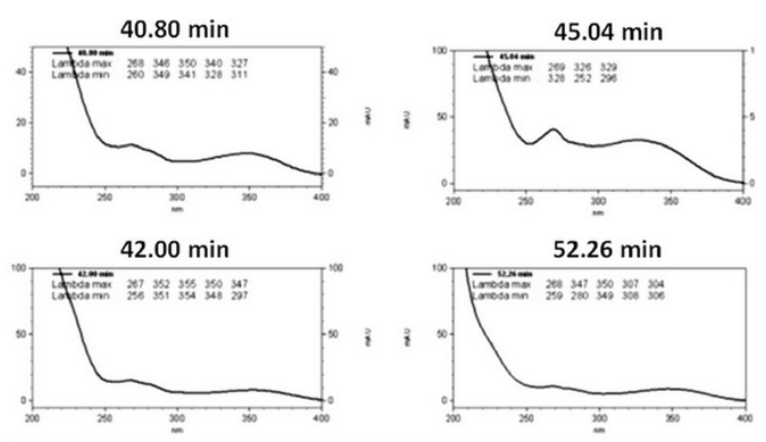

B
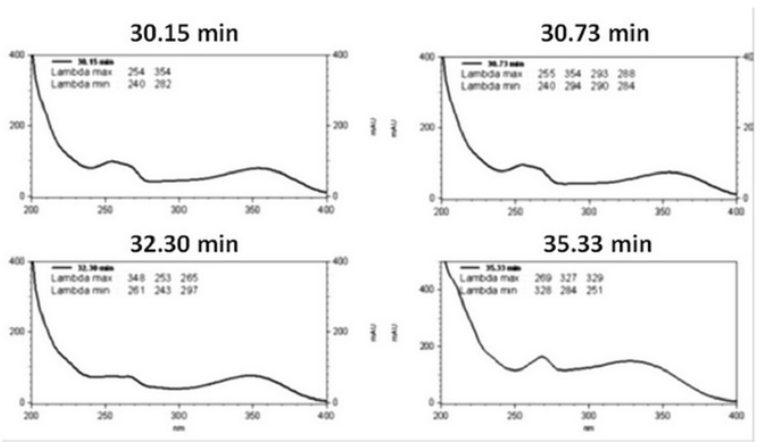

D
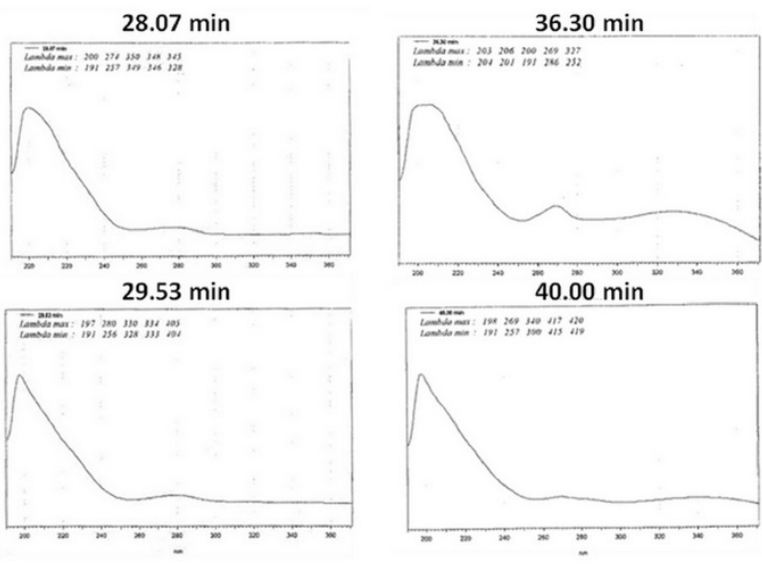

$\mathbf{F}$

Figure 1 HPLC-DAD analysis detects flavonoids as major compounds in fractions from $C$. australis. (A) EtOAc fraction from the leaves of $C$. australis showing flavonoids with RT $>40$ min. (B) UV spectra of flavonoids in the EtOAc fraction. (C) $n-B u O H$ fraction from the leaves of $C$. australis showing flavonoids with RT $<40$ min. (D) UV spectra of flavonoids in the $n$-BuOH fraction. (E) EtOAc-Pp fraction from the leaves of $C$. australis showing flavonoids and tannins with $20 \mathrm{~min}<\mathrm{RT}<50 \mathrm{~min}$. (F) UV spectra of flavonoids and tannins in the EtOAc-Pp fraction.

Molecular formula $(\mathrm{M})$ and double bond equivalent (DBE) were utilized to propose the presence of flavonols, flavones, and their glycosides and condensed tannins (dimer and trimer of flavan-3-ol). EtOAc fraction showed presence of flavonols $(\mathrm{m} / z 285,301$ and 315), condensed tannins $(m / z 529,545$ and 561), flavonol glycosides $(\mathrm{m} / z$ 447 and 463$)$ and flavone glycoside $(\mathrm{m} / z$ 477). All were detected in deprotonated form, $[\mathrm{M}-\mathrm{H}]^{-}$ion. From the $n$ - $\mathrm{BuOH}$ fraction were proposed flavonol glycosides $(\mathrm{m} / z$ 447,463 , and 609) and flavone glycosides $(\mathrm{m} / z$ 477 and 593) while the EtOAc-Pp showed the presence of flavonols and flavanones $(\mathrm{m} / z 285,289,301$ and 315), flavonol glycosides $(\mathrm{m} / z 447$ and 463$)$, flavone glycoside $(\mathrm{m} / z$ 477) and condensed tannins $(\mathrm{m} / z$ 513, 529, 545 and 769). The chemical structure of compounds identified is proposed in Table 1. 
Table 1 Proposed compounds from ESI(-)FT-ICR MS analyzes

\begin{tabular}{|c|c|c|c|c|c|c|c|c|c|}
\hline $\begin{array}{l}\text { Suggested } \\
\text { compounds }\end{array}$ & $\begin{array}{l}\text { Class of natural } \\
\text { product }\end{array}$ & $\begin{array}{l}\text { EtOAc } \\
\text { fraction }\end{array}$ & $\begin{array}{l}n-\mathrm{BuOH} \\
\text { fraction }\end{array}$ & EtOAc-Pp & $m / z_{\text {theoretical }}$ & $m / z_{\text {measured }}$ & $\begin{array}{l}\text { Molecular } \\
\text { formula (M) }\end{array}$ & $\begin{array}{l}\text { Error } \\
\text { (ppm) }\end{array}$ & DBE \\
\hline Kaempferol & Flavonol & + & - & + & 285.04046 & 285.04042 & $\mathrm{C}_{15} \mathrm{H}_{10} \mathrm{O}_{6}$ & 0.41 & 11 \\
\hline Quercetin & Flavonol & + & - & + & 301.03538 & 301.03538 & $\mathrm{C}_{15} \mathrm{H}_{10} \mathrm{O}_{7}$ & 0.25 & 11 \\
\hline Rhamnetin/isorhamnetin & Flavonol & + & & + & 315.05103 & 315.05098 & $\mathrm{C}_{16} \mathrm{H}_{12} \mathrm{O}_{7}$ & 0.33 & 11 \\
\hline Quercetin pentoside & $\begin{array}{l}\text { Flavonol } \\
\text { Monoglycoside }\end{array}$ & + & + & + & 447.09329 & 447.10361 & $\mathrm{C}_{21} \mathrm{H}_{20} \mathrm{O}_{11}$ & 0.38 & 12 \\
\hline Quercetin hexoside & $\begin{array}{l}\text { Flavonol } \\
\text { Monoglycoside }\end{array}$ & + & + & + & 463.08820 & 463.08801 & $\mathrm{C}_{21} \mathrm{H}_{20} \mathrm{O}_{12}$ & 0.38 & 12 \\
\hline $\begin{array}{l}\text { Tricetin-4'-methoxy- } \\
\text { 3'-â-D-glucoside' }\end{array}$ & $\begin{array}{l}\text { Flavone } \\
\text { Monoglycoside }\end{array}$ & + & + & + & 477.10385 & 477.10361 & $\mathrm{C}_{22} \mathrm{H}_{22} \mathrm{O}_{12}$ & -0.12 & 12 \\
\hline- & Flavan-3-ol dimer & + & - & + & 529.15041 & 529.15024 & $\mathrm{C}_{30} \mathrm{H}_{26} \mathrm{O}_{9}$ & 0.51 & 18 \\
\hline- & Flavan-3-ol dimer & + & - & + & 545.14532 & 545.14519 & $\mathrm{C}_{30} \mathrm{H}_{26} \mathrm{O}_{10}$ & & 18 \\
\hline \multirow[t]{2}{*}{-} & Flavan-3-ol dimer & + & - & - & 561.14024 & 561.08601 & $\mathrm{C}_{30} \mathrm{H}_{26} \mathrm{O}_{11}$ & 0.45 & 18 \\
\hline & Flavan-3-ol dimer & + & - & - & 591.11441 & 591.09653 & $\mathrm{C}_{30} \mathrm{H}_{24} \mathrm{O}_{13}$ & 0.40 & 19 \\
\hline $\begin{array}{l}\text { Vicenin-2 kaempferol } \\
\text { diglycoside }^{1}\end{array}$ & Flavone diglycoside & - & + & + & 593.15120 & 593.15104 & $\mathrm{C}_{27} \mathrm{H}_{30} \mathrm{O}_{15}$ & -0.08 & 13 \\
\hline Quercetin dihexoside & Flavonol diglycoside & - & + & + & 609.14611 & 609.14591 & $\mathrm{C}_{27} \mathrm{H}_{30} \mathrm{O}_{16}$ & 0.06 & 13 \\
\hline \multirow[t]{2}{*}{ - } & Flavan-3-ol trimer & - & - & + & 769.22905 & 769.22868 & $\mathrm{C}_{45} \mathrm{H}_{38} \mathrm{O}_{12}$ & 0.08 & 27 \\
\hline & Flavan-3-ol trimer & - & - & + & 785.22397 & 785.22349 & $\mathrm{C}_{45} \mathrm{H}_{38} \mathrm{O}_{13}$ & 0.08 & 27 \\
\hline
\end{tabular}

${ }^{1}$ Purified compounds identified by NMR, DBE - double bond equivalent, + detected, - not detected, Mass error $(\mathrm{ppm})=\left[\left(\mathrm{m} / \mathrm{z}_{\mathrm{measured}}-\mathrm{m} / \mathrm{z}_{\text {theoretical }}\right) / \mathrm{m} / \mathrm{z}_{\text {theoretical }}{ }^{*} 10^{6}\right.$.

\section{Cytotoxicity and antiviral activity}

EtOAc, $n-\mathrm{BuOH}$ and EtOAc-Pp fractions inhibited MAYV replication in Vero cells. EtOAc and $n-\mathrm{BuOH}$ fractions inhibited MAYV production, respectively, by more than $70 \%$ and $85 \%$ at $25 \mu \mathrm{g} / \mathrm{mL}$. EtOAc-Pp fraction inhibited MAYV production by more than $90 \%$ at $10 \mu \mathrm{g} / \mathrm{mL}$. The antiviral ribavirin were much less potent inhibitors of MAYV replication, with $\mathrm{IC}_{90}$ values above $100 \mu \mathrm{g} / \mathrm{mL}$ (Table 2 and Figure 2).

The Selectivity Index (SI) and the Relative Potency are important indexes that can represent how suitable a substance is for further studies. EtOAc-Pp had the highest SI and 16 times higher Relative Potency than ribavirin. Although this is very relevant data, further studies need to be accomplished in order to address the use of these compounds as antivirals.

\section{Discussion}

Since the three fractions tested have phenolic derivatives such as flavonoids and tannins as the major compounds, their antiviral activity can be attributed to the presence of them. EtOAc has flavonoid aglycones and flavonoid monoglycosides as major phenolics compounds, while in $n$ - $\mathrm{BuOH}$ flavonoid diglycosides are the major ones. For the fraction EtOAc-Pp, beyond flavonoid mono and diglycosides, condensed tannins are present.

The presence of condensed tannins (flavan-3-ol, dimers and trimers) may be one of the factors responsible for antiviral activity. Tannins are known for their property of complexing with proteins, including lipo- and glycoproteins. Previous studies have reported that the binding of polymeric condensed tannins with protein was stronger than that of low molecular weight oligomers and

Table 2 Cytotoxicity and anti-MAYV activity of EtOAc, n-BuOH and EtOAc-Pp fractions

\begin{tabular}{lllllll}
\hline Substance & $\mathbf{C C}_{\mathbf{5 0}}(\boldsymbol{\mu g} / \mathbf{m L})^{\mathbf{a}}$ & $\mathbf{C C}_{\mathbf{9 0}}(\boldsymbol{\mu g} / \mathbf{m L})^{\mathbf{a}}$ & $\mathbf{I C}_{\mathbf{5 0}}(\boldsymbol{\mu g} / \mathbf{m L})^{\mathbf{b}}$ & $\mathbf{I C}_{\mathbf{9 0}}(\boldsymbol{\mu g} / \mathbf{m L})^{\mathbf{b}}$ & $\mathbf{S I}^{\mathbf{c}}$ & $\mathbf{R P ^ { \mathbf { d } }}$ \\
\hline $\boldsymbol{n}$-BuOH & $2614 \pm 366$ & $821 \pm 115$ & $7,1 \pm 1,0$ & $89,9 \pm 5,7$ & $\mathbf{2 0}$ & $\mathbf{1 0}$ \\
EtOAc & $457,7 \pm 9,5$ & $176,1 \pm 3,5$ & $8,2 \pm 0,2$ & $4,7 \pm 0,3$ & 2 & 1 \\
EtOAc-Pp & $324,1 \pm 6,5$ & $154,7 \pm 3,1$ & $2,5 \pm 0,1$ & $112,4 \pm 8,2$ & 33 & 2 \\
ribavirin & $523,1 \pm 42,5$ & $215,4 \pm 6,2$ & $62,3 \pm 4,4$ & $\mathrm{nd}$ \\
\hline
\end{tabular}

${ }^{\mathrm{a}} 50 \%$ and $90 \%$ cytotoxic concentration.

$\mathrm{b}_{50 \%}$ and $90 \%$ inhibitory concentration of viral replication.

'Selectivity Index = standard IC ${ }_{90}$ /substance $\mathrm{IC}_{90}$.

${ }^{d}$ Relative Potency $=$ ratio between ribavirin (reference substance) $I C_{90}$ and the tested substance's $I C_{90}$.

nd - Not determined. 


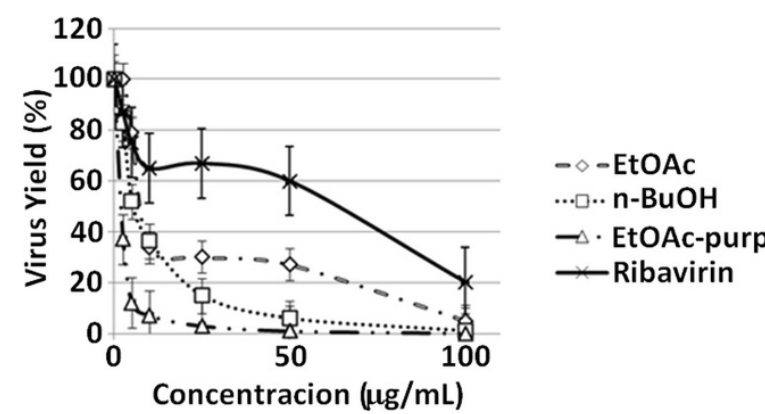

Figure 2 Anti-MAYV activity of different fractions from $C$. australis. The anti-MAYV activity of EtOAc, $n-B u O H$ and EtOAc-Pp fractions from C. australis was evaluated by treating MAYV-infected cells with $0-100 \mu \mathrm{g} / \mathrm{ml}$ of these fractions for $24 \mathrm{~h}$, and then staining for viral plaque counting. The graph shows the results from three independent experiments. Data are presented as mean\% virus yield (compared to untreated controls) $\pm \mathrm{SD}$.

monomers. It is believed that hydrogen bonding is an important factor in the binding of condensed tannins gelatin [34].

We know that the effect of the astringent polyphenols, including flavonoids and tannins, is dependent on the affinity of these substances with the protein and due to this is greatly influenced by the composition of each protein, as well as their hydrophilicity, therefore different viruses react polyphenols to different manner. In addition, previous works suggest the tannin-like proanthocyanidins may link the protein covalently [35].

Takechi et al. [36] concluded in his work more highly condensed tannins have a greater antiviral activity, although the galloyl group contributes more to activity than the degree of condensation. It is known that the presence of o-dihydroxyphenyl group is related to the formation of protein-polyphenol complex. Moreover, it is thought that tannins interact with the protein particles from the surface of the host cell of the virus, as well as to the viral envelope [36].

In a previous study, Ferreira et al. found that the flavonoids quercetin group had a strong antiviral activity against MAYV, suggesting that this virus has proteins that are able to interact with phenolic substances from the group of flavonoid envelope [37].

Condensed tannins have been tested for their antiviral activity and exhibited antiviral activity against respiratory syncytial virus (RSV), influenza A virus (FLU-A) and parainfluenza virus (PIV). It also inhibited the growth of herpes viruses types 1 and 2 (HSV-1, HSV-2) and hepatitis $\mathrm{A}$ and $\mathrm{B}$ viruses. The proposed mechanism of action was from its connection with the viral envelope proteins, inhibiting the binding and penetration of the virus in the plasma membrane [38].

Yang et al. [39] compared several polyphenols derived from tea against influenza $A$ and $B$ and concluded that condensed tannins were the most active against the influenza A virus than monomeric polyphenols: theaflavin, procyanidin B-2 and procyanidin B-2. To evaluate the structure-activity relationship, they concluded that the dimers as theaflavin and procyanidin B-2, are more active against influenza $\mathrm{A}$ and $\mathrm{B}$ than the catechin monomers, such as (-)-EC and ( \pm )-catechin and that galoyl group present in theaflavindigallate and procyanidin B-2 digallate not help on antiviral effect, probably due to the steric effect [39].

Since the trimers of tannins are only present in EtOAc-Pp, we correlate this to the greater antiviral activity of this fraction. Previous studies have shown that the degree of condensation is an important factor $[36,39]$, being more highly condensed tannins more active; we believe that these substances are responsible for anti-viral activity.

\section{Conclusions}

Our results show that $C$. australis is a valuable source of phenolics derivates with antiviral activity against the arbovirus MAYV. Although antiviral activity of tannins and other phenolics derivates are very common, this is the first report of anti-MAYV activity for these substances and this species. Our data are an important step in the evaluation of natural products as sources of novel drugs to be used in combination therapy, to circumvent drug resistance, or to replace currently used antivirals with unwanted cytotoxic effects.

\section{Competing interests}

The authors declare that they have no competing interests.

\section{Authors' contributions}

RMK and DF conceived and designed the study. AS collected plant material with KCWS. KCWS performed all phytochemical experiments and wrote the initial draft of the manuscript. TSS performed cytotoxicity and viral yield inhibition assays. WR made the ESI(-)FT-ICR MS analyses. MDFM, RC and NKS revised the data and carried out statistical analyses. KCWS, RMK and DF provided invaluable discussions on the chemical data and antiviral chemistry. All authors read and approved the final manuscript.

\section{Acknowledgements}

The authors would like to thank CNPq and INBEB for financial support.

\section{Author details}

${ }^{1}$ Natural Product Research Institute, Center of Health Sciences, Federal University of Rio de Janeiro, Rio de Janeiro, Brazil. ${ }^{2}$ Natural Product and Food Department. Center of Health Sciences, Federal University of Rio de Janeiro, Rio de Janeiro, Brazil. ${ }^{3}$ Microbiology Institute, Virology Department, Federal University of Rio de Janeiro, Rio de Janeiro, Brazil. ${ }^{4}$ Chemistry Institute, Biochemistry Department, Federal University of Rio de Janeiro, Rio de Janeiro, Brazil. ${ }^{5}$ Botanical Department. Center of Biological and Health Sciences, Federal University of the State of Rio de Janeiro, Rio de Janeiro, Brazil. 'Petroleomic and Forensic Laboratory, Department of Chemistry, Federal University of Espírito Santo, 29075-910 Vitória, ES, Brazil.

Received: 23 July 2014 Accepted: 12 November 2014

Published online: 27 November 2014 


\section{References}

1. Vasconcelos PFC, Rosa APAT, Pinheiro FP, Shope RE, Rosa JFST, Rodrigues SG, Dégallier N, Travassos da Rosa ES: Arboviruses pathogenic for man in Brazil. In An overview of arbovirology in Brazil and neighbouring countries. Edited by Rosa APAT, Vasconcelos PFC, Rosa JFST. Belém: Instituto Evandro Chagas; 1998:72-99

2. Coimbra TLM, Santos CLS, Suzuki A, Petrella SMC, Bisordi I, Nagamori AH, Marti AT, Santos RN, Fialho DM, Lavigne S, Buzzar MR, Rocco IM: Mayaro virus: imported cases of human infection in São Paulo state, Brazil. Rev Inst Med Trop Sao Paulo 2007, 4:221-224.

3. Pinheiro FP, Travassos Da Rosa APA, Travassos Da Rosa JFS, Ishak R, Freitas RB, Gomes MLC, Le Duc JW, Oliva OFP: Oropouche virus. I. A review of clinical, epidemiological, and ecological findings. Am J Trop Med Hyg 1981, 30:149-160.

4. Pinheiro FP, Freitas RB, Rosa JFT, Gabbay YB, Mello WA, LeDuc JW: An outbreak of Mayaro virus disease in Belterra, Brazil. I. Clinical and virological findings. Am J Trop Med Hyg 1981, 30:674-681.

5. Vasconcelos PF, Travassos da Rosa AP, Rodrigues SG, Travassos da Rosa ES, Dégallier N, Travassos da Rosa JF: Inadequate management of natural ecosystem in the Brazilian Amazon region results in the emergence and reemergence of arboviruses. Cad Saude Publica 2001, 17:155-164.

6. Receveur MC, Grandadam M, Pistone T, Malvy D: Infection with Mayaro virus in a French traveller returning from the Amazon region, Brazil. Euro Surveill 2010, 18:1-4.

7. Brasil, Ministério da Saúde. Ministério da Saúde intensifica medidas de controle da febre Chikungunya. Accessed 11.03.2014. [http://portalsaude. saude.gov.br/index.php/o-ministerio/principal/secretarias/svs/noticias-svs/ 14667-ministerio-da-saude-intensifica-medidas-de-controle-da-febrechikungunya]

8. Brasil, Ministério da Saúde. Saúde atualiza situação do vírus Chikungunya Accessed 11.03.2014. [http://u.saude.gov.br/d0ya9751]

9. George DR, Finn RD, Graham KM, Sparagano OAE: Present and future potential of plant-derived products to control arthropods of veterinary and medical significance. Parasit Vectors 2014, 7:1-12.

10. Yasuhara-Bell J, Yuanan L: Marine compounds and their antiviral activities. Antiviral Res 2010, 86:231-240.

11. Newman DJ, Cragg GM: Natural products as sources of new drugs over the 30 years from 1981 to 2010. J Nat Prod 2012, 75:311-335.

12. Irwin HS, Barneby RC: The American Cassiinae: a synoptical revision of Leguminosae tribe Cassieae subtribe Cassiinae in the New World. Mem New York Bot Gard 1982, 35:1

13. Wiersema JH: A new name for a Brazilian Senna (Leguminosae: Caesalpinoideae). Taxon 1989, 38:652-652.

14. Viegas C Jr, Rezende A, Silva DHS, Castro-Gambôa I, Bolzani VS, Barreiro EJ, Miranda ALP, Moreira MSA, Young MCM: Aspectos químicos, biológicos e etnofarmacológicos do gênero Cassia. Quim Nova 2006, 29:1279-1286.

15. Nsonde Ntandou GF, Banzouzi JT, Mbatchi B, Elion-Itou RDG, Etou-Ossib AW, Ramos S, Benoit-Vical F, Abena AA, Ouamba JM: Analgesic and anti-inflammatory effects of Cassia siamea Lam. Stem bark extracts. J Ethnopharmacol 2010, 127:108-111.

16. Guzmán E, Pérez C, Zavala MA, Acosta-Viana KY, Pérez S: Antiprotozoal activity of (8-hydroxymethylen)-trieicosanyl acetate isolated from Senna villosa. Phytomedicine 2008, 15:892-895.

17. Lombardo M, Kiyota S, Kaneko TM: Aspectos étnicos, biológicos e químicos de Senna occidentalis (Fabaceae). Rev Ciênc Farm Básica Apl 2009, 30:1-9.

18. Longuefosse JL, Nossin EJ: Medical ethnobotany survey in Martinique. J Ethnopharmacol 1996, 53:117-142.

19. Franco EAP, Barros RFM: Uso e diversidade de plantas medicinais no Quilombo Olho D'água dos Pires, Esperantina, Piauí. Rev Bras Plantas Med 2006, 8:78-88.

20. Jones L, Bartholomew B, Latif Z, Sarker SD, Nash RJ: Constituents of Cassia laevigata. Fitoterapia 2000, 71:580-583.

21. Silva ALG, Ormond WT, Pinheiro MCB: Biologia floral e reprodutiva de Senna australis (Vell.) Irwin \& Barneby (Fabaceae, Caesalpinioideae). Bol Mus Nac NS Bot 2002, 121:1-11.

22. dos Santos RN, Silva MGV, Braz FR: Constituintes químicos do caule de Senna reticulata Willd. (Leguminoseae). Quim Nova 2008, 31:1979-1981.

23. Barbosa FG, Oliveira MCF, Braz-Filho R, Silveira ER: Anthraquinones and naphthopyrones from Senna rugosa. Biochem Syst Ecol 2004, 32:363-365.
24. Hennebelle T, Weniger B, Joseph H, Sahpaz S, Bailleul F: Senna alata. Fitoterapia 2009, 80:385-393.

25. Kanno M, Shibano T, Takido M, Kitanaka S: Antiallergic agent from natural sources. 2. Structures and leukotriene release-inhibitory effect of torososide B and torosachrysone 8-0-6"-malonyl beta-gentiobioside from Cassia torosa Cav. Chem Pharm Bull 1999, 47:915-918.

26. Dehmlow EV, van Ree T, Guntenhöner M: 2,4-trans-,7 4'-dihydroxy-4methoxyflavan from Cassia abbreviata. Phytochemistry 1998, 49:1805-1806.

27. Coetzeea J, Mcitekaa L, Malana E, Ferreira D: Structure and synthesis of the first procassinidin dimers based on epicatechin, and gallo- and epigallo-catechin. Phytochemistry 2000, 53:795-804.

28. Hatano T, Mizuta S, Ito H, Yoshida T: C-Glycosidic flavonoids from Cassia occidentalis. Phytochemistry 1999, 52:1379-1383.

29. Hatano T, Yamashita A, Hashimoto T, Ito H, Kubo N, Yoshiyama M, Shimura S, Itoh Y, Okuda T, Yoshida T: Flavan dimers with lipase inhibitory activity from Cassia nomame. Phytochemistry 1997, 46:893-900.

30. Viegas C Jr, Bolzani VS, Furlan M, Barreiro EJ, Young MCM, Tomazela D, Eberlin MN: Further bioactive piperidine alkaloids from the flowers and green fruits of Cassia spectabilis. J Nat Prod 2004, 67:908-910.

31. Yuping $T$, Weiping $Z$, Fengchang L, Yanfang L, Jinghua W: Flavone Glycosides from the Leaves of Ginkgo biloba. J Chin Pharmaceut Sci 2009, 9:119-121.

32. Xie C, Veitch NC, Houghton PJ, Simmonds MSJ: Flavone C-Glycosides from Viola yedoensis Makino. Chem Pharm Bull 2003, 51:1204-1207.

33. Borenfreund $E$, Puerner JA: Toxicity determined in vitro by morphological alterations and neutral red absorption. Toxicol Lett 1985, 24:119-124.

34. Frazier RA, Deaville ER, Green RJ, Stringano E, Willoughby I, Plant J, Mueller-Harvey I: Interactions of tea tannins and condensed tannins with proteins. J Pharm Biomed Anal 2010, 51:490-495.

35. Gescher K, Kühn J, Lorentzen E, Hafezi W, Derksen A, Deters A, Hensel A: Proanthocyanidin-enriched extract from Myrothamnus flabellifolia Welw. exerts antiviral activity against herpes simplex virus type 1 by inhibition of viral adsorption and penetration. J Ethnopharmacol 2011, 24:468-474.

36. Takechi M, Tanaka Y, Takehara M, Nonaka G, Nishioka I: Structure and antiherpetic activity among the Tannins. Phytochemistry 1985, 24:2245-2250.

37. dos Santos AE, Kuster RM, Yamamoto KA, Salles TS, Campos R, de Meneses $M D F$, Soares MR, Ferreira D: Quercetin and quercetin 3-Oglycosides from Bauhinia longifolia (Bong.) Steud. show anti-Mayaro virus activity. Parasit Vectors 2014, 7:130.

38. De Bruyne T, Pieters L, Deelstra H, Vlietinck A: Condensed vegetable tannins: Biodiversity in structure and biological activities. Biochem Sys Ecol 1999, 27:445-459.

39. Yang ZF, Bai LP, Huang WB, Li XZ, Zhao SS, Zhong NS, Jiang ZH: Comparison of in vitro antiviral activity of tea polyphenols against influenza $A$ and $B$ viruses and structure-activity relationship analysis. Fitoterapia 2014, 93:47-53.

doi:10.1186/s13071-014-0537-z

Cite this article as: Spindola et al:: Anti-Mayaro virus activity of Cassia australis extracts (Fabaceae, Leguminosae). Parasites \& Vectors 2014 7.537.

\section{Submit your next manuscript to BioMed Central and take full advantage of:}

- Convenient online submission

- Thorough peer review

- No space constraints or color figure charges

- Immediate publication on acceptance

- Inclusion in PubMed, CAS, Scopus and Google Scholar

- Research which is freely available for redistribution 